\title{
VARIABILITY AND HERITABILITY OF TYPE TRAITS OF HOLSTEIN-FRIESIAN BULL DAMS
}

\author{
V. Pantelić ${ }^{1}$, D. Nikšić ${ }^{1}$, S. Trivunović ${ }^{2}$ \\ ${ }^{1}$ Institute for Animal Husbandry, Belgrade-Zemun, Republic of Serbia \\ ${ }^{2}$ Faculty of Agriculture, Novi Sad, Republic of Serbia \\ Corresponding author: vladap4@gmail.com \\ Invited paper
}

Abstract: Objective of this study was to calculate the variability and heritability of type traits in the nucleus herd of bull dams by using the linear method of evaluation, and to determine their importance in selection of cattle. Study included 127 Holstein-Friesian cows selected as bull dams on cattle farms of PKB Korporacija, Belgrade. By applying the Least square method, main variationstatistical parameters were calculated: arithmeitc mean, standard deviation, variation coefficient, standard error and variation range. Bull dams of HolsteinFriesian breed had average milk production of $10245.98 \mathrm{~kg}$, with variation range from $6514 \mathrm{~kg}$ to $13251 \mathrm{~kg}$. Average milk fat yield was $361.95 \mathrm{~kg}$, and milk fat content 3,53\%. Average values for type scores of Holstein-Friesian bull dams were: rump height 5.40 , chest width 7.09 , body depth 7.38 , rump position 5.39, rump width 6.55 , dairy form 7.35 , rear legs set (rear view) 5.22, rear legs set (side view) 5.28 , hoof angle 5.27 , fore udder 6.65 , front teats placement 5.43 , teat length 4.76, udder depth 6.96, rear udder height 7.13, suspensory ligament 7.08 and rear teats placement 5.89. Also, heritability coefficients and errors were calculated for all milk and type traits. Type and body development scores are very important indicators of production ability of cows, their potential to consume sufficient quantities of food, produce high quality milk from the technological aspect, reduce the use of energy in production and remain as long as possible in exploitation.

Key words: type traits, bull dams, heritability, milk performance.

\section{Introduction}

Linear type traits are basis of contemporary classification systems, and represent foundation of all systems used in description of dairy cattle. Linear classification is based on measures/measuring of individual type traits instead of giving opinion. It describes the degree to which certain trait is present, and not desirability. 
Body development and type are very important indicators of production abilities of cows, their potential to consume sufficient quantities of food, produce high quality milk from the technological aspect, reduce the use of energy in production and remain as long as possible in production giving a larger number of offspring (Pantelić et al. 2009).

Stojić et al. (2002) state that in linear type scoring of Black and White cattle 14 traits are included, 6 are body development traits and 8 are udder traits. The average expression of trait is given the score 5. For following 4 traits: rump position, rear legs set, udder balance and teat size, this score is preferable. For remaining traits higher score value is preferable.

Živanović (2002) studied the variability of linear type scores and milk traits of Black and White cattle on sample of 2.976 cows. The scoring system including 14 traits, 6 traits of body development and 8 udder traits. Average values of obtained scores were in range from 5,28 to 7,15 for body development, and from 5,06 to 7,02 for udder traits.

Average values of type scores obtained for Holstein-Friesian bull dams were established in study by Pantelic et al. (2010a): body height 7.11, strength and capacity 7.34 , dairy form 7.23 , rump width 6.31 , rump position 5.29 , rear legs set 5.10, fore udder attachment 6.69 , rear udder height 6.95 , rear udder width 7.31 , udder depth 6.70, suspensory ligament 6.85 , udder balance 5.17 , teat placement 5.96 , and teat length 5.23.

In the investigation of the heritability of type traits in Black and White first-calving cows, Pantelić et al. (2010b), established average values of heritability coefficients in the range from 0.066 (rear legs set) to 0.310 (rump width), whereas the value of the heritability coefficient for dairy form expression was 0.293 . Other three traits had similar values of the heritability coefficient (height to withers 0.155 , strength and capacity 0.187 and rump position0.178). The lowest heritability values in group of udder traits were established for: udder balance $(0.045)$ and suspensory ligament (0.097). Slightly higher heritability values were determined for teat placement and udder depth $(0.103$ and 0.167 , respectively). Medium heritability coefficients were registered for fore udder (0.244), rear udder width (0.293) and teat length (0.262). The highest scored heritability value was for rear udder height -0.441 . Values of the heritability error were in range from 0.022 to 0.116 .

\section{Materials and Methods}

In order to produce Holstein-Friesian bulls it is necessary to select the best cows from the herd under control. Bull dams,as a rule, represent about $1 \%$ of best cows of population under control and primarily in regard to milk performance and 
milk fat yield, but also in regard to body development, udder composition and fertility traits (Pantelić, 2004.).

Linear type and body development scoring of cattle is done according to determined criteria, individually or in so called selection inspection/control by direct insight into appearance and condition of animals. Preferably, cows are scored/evaluated in the first lactation from 30. to 150. day after calving because of the activity and capacity of udder in this period and assumption that the genetic basis is more certain for scoring in this period, and that the impact of the environment factors is not so pronounced (Pantelić et al. 2007a). Even though linear type scoring does not describe the desirability of certain trait, score 9 will represent either the most desirable or least desirable score of two possible extremes.

The study included 127 cows of Holstein-Friesian breed selected as bull dams on farms of PKB Korporacija. Bull dams were selected by a team of experts consisting of three members, representatives of the regional and primary/main selection-breeding organization and livestock-veterinary centre. Selection of cows for the herd of bull dams was done after the first lactation was completed, i.e. based on subsequent lactations. During their selection, cows' exterior was measured and body development scored.

Results of the study of heritability and variability of production and linear scores of type traits were obtained by using the following model:

$\mathrm{Y}_{\mathrm{ijkl}}=\mu+\mathrm{O}_{\mathrm{i}}+\mathrm{F}_{\mathrm{j}}+\mathrm{L}_{\mathrm{k}}+\mathrm{e}_{\mathrm{ijkl}}$

$\mathrm{Y}_{\mathrm{ijk}}=$ phenotypic value of traits included in the analysis

$\mu=$ general mean value

$\mathrm{O}_{\mathrm{i}}=$ fixed effect of $i$ bull sire

$\mathrm{F}_{\mathrm{j}}=$ fixed effect of $j$ farm

$\mathrm{L}_{\mathrm{k}}=$ fixed effect of $k$ lactation

$\mathrm{e}_{\mathrm{ijklm}}=$ random error (other uncontrolled effects)

Main variation-statistical parameters were calculated for studied type traits

and milk performance traits: arithmetic mean $(\bar{X})$, standard deviation (SD), variation coefficient $(\mathrm{CV})$, standard error of the average $(\mathrm{S} \bar{X})$, variation range (Min-Max).

\section{Results and Discussion}

Practically, by selection the genetic basis of individual animal, populations and breeds is changed, with goal to obtain new genotypes which would enable maximum production performance and economic effects. Visual assessment and recognition of dairy form in cows are preliminary indicators of milk production, 
and to certain extent also of longevity and reproduction ability of animals, which is also important aspect of the economical efficiency of milk production.

Realization of the genetic progress in cattle breeding is usually accomplished in smaller, elite, so called nucleus herds, and subsequently through implementation of certain breeding procedures realized progress is spread to the remaining population. How will the genetic progress realized in the nucleus herd be achieved in the rest of population depends on several factors among which the most important are the complexity of the breeding program, bio-economical characteristics of traits, level of the selection intensity, remount percentage, duration of the generation interval, etc.

Average values and variability of milk traits and linear type scores of Holstein-Friesian bull dams are presented in Table 1.

Table 1. Average values and variability of milk traits and linear type scores of Holstein-Friesian bull dams

\begin{tabular}{|l|c|c|c|c|c|c|c|}
\hline & $\mathrm{n}$ & $\bar{x}$ & $\mathrm{~S} \bar{x}$ & $\mathrm{SD}$ & $\mathrm{CV}$ & Min. & Max. \\
\hline MY,kg & 127 & 10245,98 & 136,72 & 1540,83 & 15,03 & 6514 & 13251 \\
\hline MF, $\%$ & 127 & 3,53 & 0,01 & 0,18 & 5,27 & 2,80 & 3,89 \\
\hline MF, kg & 127 & 361,95 & 5,03 & 56,78 & 15,68 & 225,40 & 485,51 \\
\hline RH & 127 & 5,40 & 0,11 & 1,33 & 24,71 & 3,000 & 8,00 \\
\hline CW & 127 & 7,09 & 0,06 & 0,74 & 10,52 & 4,000 & 8,00 \\
\hline BD & 127 & 7,38 & 0,05 & 0,60 & 8,17 & 6,000 & 9,00 \\
\hline RP & 127 & 5,39 & 0,05 & 0,57 & 10,73 & 4,000 & 7,00 \\
\hline RW & 127 & 6,55 & 0,07 & 0,88 & 13,55 & 4,000 & 9,00 \\
\hline DF & 127 & 7,35 & 0,04 & 0,51 & 6,96 & 6,000 & 8,00 \\
\hline RLSRV & 127 & 5,22 & 0,09 & 1,03 & 19,88 & 3,000 & 8,00 \\
\hline RLSSV & 127 & 5,28 & 0,05 & 0,66 & 12,56 & 4,000 & 7,00 \\
\hline HA & 127 & 5,27 & 0,08 & 1,00 & 19,05 & 3,000 & 7,00 \\
\hline FUA & 127 & 6,65 & 0,07 & 0,86 & 13,03 & 5,000 & 8,00 \\
\hline FTP & 127 & 5,43 & 0,09 & 1,05 & 19,36 & 3,000 & 8,00 \\
\hline TL & 127 & 4,76 & 0,07 & 0,82 & 17,31 & 2,000 & 7,00 \\
\hline UD & 127 & 6,96 & 0,07 & 0,81 & 11,64 & 4,000 & 8,00 \\
\hline RUH & 127 & 7,13 & 0,05 & 0,61 & 8,66 & 5,000 & 8,00 \\
\hline SL & 127 & 7,08 & 0,06 & 0,78 & 11,05 & 5,000 & 8,00 \\
\hline RTP & 127 & 5,89 & 0,10 & 1,13 & 19,27 & 4,000 & 8,00 \\
\hline
\end{tabular}

MY - milk yield; MF, \% - percentage of milk fat; MF, kg - Yield of milk fat; RH-Rump height; CW Chest width; BD - Body depth; RP - Rump position; RW - Rump width; DF - Dairy form; RLSRVRear legs set, rear view; RLSSV- Rear legs set, side view; HA - Hoof angle; FUA-Fore udder attachment; FTP - Front teat placement; TL-Teat length; UD - Udder depth; RUH-Rear udder height; SL- Suspensory ligament; RTP - Rear teat placement. 
Bull dams of Holstein-Friesian breed have achieved average milk yield of $10245.98 \mathrm{~kg}$, with variation range from $6514 \mathrm{~kg}$ to $13251 \mathrm{~kg}$. Average milk fat yield was $361.95 \mathrm{~kg}$, and milk fat content $3,53 \%$.

Average values of linear type scores obtained by using the Least square method in this research were in the range from 4.76 (teat length) to 7.38 (body depth). Score for rump position was very close to preferable score (5) - 5.39. Scores for rear legs set, side and rear view, were approximately the same (5.22 and 5.28 ), and very close to desired score of 5 awarded for animals with proper position/posture. Udder scores ranged from 5.43 (front teat placement) to 7.13 (rear udder height). Rear teat placement was scored with average score of 5.89, udder depth 6.96, and strength of suspensory ligament 7.08.

Comparing of linear type scores with results obtained in similar studies is rather difficult because of differences in scoring systems, various traits that are being evaluated, as well as breeds. If linear type scores are compared to results obtained by other authors, regardless of the score scale used, it can be concluded that obtained results are similar to those reported by Pantelić et al. (2010a), and Živanović (2002).

Taking into consideration the fact that linear type score is based on assumption that traits being scored have normal distribution through the population, i.e. that there is small number of animals with extremely bad or good characteristics, it is possible to treat these traits as quantitative properties. Therefore, it is possible to apply certain methodological procedures to determine the degree of transmission of these properties/traits to their progeny.

Linear scores are used also in selection of breeding animals, in a way to try always to choose parent animals which mutually compensate their deficiencies in the exterior (Pantelic et al. 2007b). However, in majority of breeding programs, main issue in the genetic improvement of functional traits (health condition, fertility, leg traits and longevity) is lack of proper and adequate control and recording of these properties, i.e. control/recording is often only moderately associated with the physiological condition (Swalve, 2003).

Heritability, as value which expresses and measures the average additive gene effect, is one of the major characteristics of quantitative traits from the aspect of creating of high valuable cattle populations. The heritability level represents the ratio between the variations as results of the genotype effect and total variance which includes all influences.

Heritability coefficients of linear type scores are presented in Table 2 . Heritability coefficient for milk yield was 0,44 , for milk fat percentage - 0,12 and quantity of milk fat - 0,42 .

Heritability coefficients for traits of body development were in range from 0.03 (rear legs set, side view) to 0.85 (rump width), whereas the value of the heritability coefficient for dairy form was 0.23 . Other traits had following 
heritability coefficient values: rump height -0.31 , rump position -0.39 , chest width and body depth -0.05 and hoof angle -0.51 .

The lowest heritability values in the group of udder traits were reported for teat length (0.01) and suspensory ligament (0.05). Slightly higher values of heritability were obtained for front teat placement and rear udder height $(0.19$ and 0.20 , respectively). Medium values of heritability coefficient were established for rear teat placement $(0.34)$. The highest heritability value was determined for following traits: fore udder attachment -0.57 and udder depth -0.64 . Heritability error values were in the range from 0.03 to 0.41 . Obtained results differ from values reported by Pantelić et al. (2010b), because they refer to bull dams which are elite heads of the herd under control.

Table 2. Heritability $\left(\mathrm{h}^{2}\right)$ and standard heritability error $\left(\mathrm{sh}^{2}\right)$ of milk traits and linear type scores of Holstein-Friesian bull dams

\begin{tabular}{|l|c|c|}
\hline & $\mathrm{h}^{2}$ & $\mathrm{sh}^{2}$ \\
\hline TRAITS & 0,44 & 0,39 \\
\hline Milk yield & 0,12 & 0,06 \\
\hline Milk fat, \% & 0,42 & 0,39 \\
\hline Milk fat, kg & 0,31 & 0,29 \\
\hline Rump height & 0,05 & 0,03 \\
\hline Chest width & 0,05 & 0,03 \\
\hline Body depth & 0,39 & 0,31 \\
\hline Rump position & 0,85 & 0,41 \\
\hline Rump width & 0,23 & 0,19 \\
\hline Dairy form & 0,04 & 0,03 \\
\hline Rear legs set, rear view & 0,03 & 0,03 \\
\hline Rear legs set, side view & 0,51 & 0,39 \\
\hline Hoof angle & 0,57 & 0,40 \\
\hline Fore udder attachment & 0,19 & 0,09 \\
\hline Front teat placement & 0,01 & 0,37 \\
\hline Teat length & 0,64 & 0,40 \\
\hline Udder depth & 0,20 & 0,19 \\
\hline Rear udder height & 0,05 & 0,03 \\
\hline Suspensory ligament & 0,34 & 0,29 \\
\hline Rear teat placement & & \\
\hline
\end{tabular}


Heritability values of type traits in the studies by numerous authors show great variability depending on the breed, housing system and scoring system. Weigel et al. (1998) established heritability values for 14 type traits in range from 0,15 (pastern angle) to 0,42 (stature). Similar heritability values of type traits in range from 0,11 to 0,43 are stated by Smith et al. (1998), Van Dorp et al. (1998), as well as association Semex Deutschland (2001).

Some of the potential explanations or reasons for such difference in heritability coefficient values could be housing conditions and nutrition of cows on farms, i.e. applied management, exhibiting influence on total variation of traits.

Rearing, i.e. breeding values of bulls and cows must be based on classification of cows in the first lactation, assessed within the scoring system of the herd. Within the herd scoring system, all cows in the first lactation, that haven't been previously scored, must be scored by the person doing the classification during the visit. Additional classifications/scoring for the purpose of obtaining data for breeding male animal are possible provided that they are realized by the same organization, and that daughters have been selected by method of random sample with sufficient number of animals of same age that can be scored during one visit, i.e. scoring.

\section{Conclusion}

Studies indicate that linear type scores should be included in total evaluation of the breeding value of animals, and gain complete insight into genetic superiority, especially in case of breeding bulls. The use of semen obtained from bulls that are superior in transmission of preferable traits of body development to wide population of cattle will result in faster realization of herds with type uniform animals, of good conformation, health condition and longevity, which could be achieved by practical implementation of the system of corrective matings.

Visual assessment and recognizing of cows' dairy form are preliminary indicators of milk production, and to some extent also of longevity and reproduction performance of animals, which is very important from the aspect of economical efficiency of milk production.

By taking into account exterior of offspring and their proper selection, the possibility of transmission of negative traits carried by the parent animals as recessive, which can be spread through whole population very fast as the results of artificial insemination, to the progeny is reduced.

With implementation of intensive selection the genetic variability is reduced, and at the same time the heritability. The knowledge of the heritability coefficients is very important in evaluation of the breeding value of farm animals, and also contributes considerably to the proper choice of rearing to method. 


\title{
Acknowledgment
}

Research was financed by the Ministry of Education and Science, Republic of Serbia, project TR-31053.

\section{Varijabilnost i naslednost osobina tipa bikovskih majki holštajn frizijske rase}

\author{
V. Pantelić, D. Nikšić, S. Trivunović
}

\section{Rezime}

Cilj ovih istraživanja bio je da se u nukleus zapatu bikovskih majki primenom linearnog metoda ocenjivanja krava izračuna varijabilnost $i$ heritabilitet osobina tipa, i njihov značaj u selekciji goveda. Istraživanjem je obuhvaćeno 127 krava holštajn frizijske rase odabrane u kategoriju bikovskih majki na farmama PKB Korporacije, Beograd. Za sve ispitivane osobine primenom metoda najmanjih kvadrata izračunati su osnovni varijaciono-statistički parametri: aritmetička sredina, standardna devijacija, koeficijenti varijacije, standardna greška i interval varijacije. Bikovske majke holštajn frizijske rase ostvarile su prosečnu proizvodnju mleka od $10245.98 \mathrm{~kg}$, pri čemu je interval variranja bio od $6514 \mathrm{~kg}$ do $13251 \mathrm{~kg}$. Prosečna proizvodnja mlečne masti iznosila je $361,95 \mathrm{~kg}$, a sadržaj mlečne masti $3,53 \%$. Prosečne vrednosti ocene tipa bikovskih majki holštajn frizijske rase iznosile su: visina krsta 5,40, širina grudi 7,09, dubina tela 7,38, položaj karlice 5,39 , širina karlice 6,55 , mlečne karakteristike 7,35 , položaj zadnjih nogu otpozadi 5,22 , položaj zadnjih nogu sa strane 5,28 , ugao papaka 5,27 , prednja veza vimena 6,65 , pozicija prednjih sisa 5,43 , dužina sisa 4,76 , dubina vimena 6,96 , visina zadnjeg vimena 7,13 , centralni ligament 7,08 i položaj zadnjih sisa 5,89. Osim toga za sve osobine mlečnosti i tipa izračunati su koeficijenti heritabiliteta i njihove greške. Ocene tipa i telesne razvijenosti su veoma važni pokazatelji proizvodnih sposobnosti krava, njihovih mogućnosti da konzumiraju dovoljne količine hrane, daju tehnološki kvalitetno mleko, smanje utrošak energije u proizvodnji i što duže ostanu u eksploataciji.

\section{References}

BULLENKATALOG, februar 2001., Semex Deutschland.

PANTELIĆ V. (2004): Fenotipska varijabilnost proizvodnih i reproduktivnih osobina bikovskih majki simentalske rase. Magistarska teza, Poljoprivredni fakultet, Beograd. 
PANTELIĆ V., SKALICKI Z., PETROVIĆ M.M., LATINOVIĆ D., ALEKSIĆ S., MIŠČEVIĆ B., OSTOJIĆ D. (2007a): Linearno ocenjivanje bikovskih majki simentalske rase. Savremena poljoprivreda, 1-2, 49-53.

PANTELIĆ V., SKALICKI Z., PETROVIĆ M.M., ALEKSIĆ S., MIŠČEVIĆ B., OSTOJIĆ-ANDRIĆ D. (2007b): Variability of linearly evaluated traits of type of Simmental bull dams. Biotechnology in Animal Husbandry, 23, 5-6, Book 1, 201209.

PANTELIĆ V., SKALICKI Z., BOGDANOVIĆ V., DELIĆ N., PEJČIĆ S. (2009): The effect of paragenetic factors on body development of simmental bull dams. Biotechnology in Animal Husbandry, 25, 1-2, 53-59.

PANTELIĆ V., ALEKSIĆ S., OSTOJIĆ-ANDRIĆ D., SRETENOVIĆ LJ., PETROVIĆ M.M., NOVAKOVIĆ Ž. (2010a): Linear evaluation of the type of holstein-friesian bull dams. Archiva zootechnica, 13, 1, 83-60.

PANTELIĆ V., SAMOLOVAC Lj., ALEKSIĆ S., TRIVUNOVIĆ S., PETROVIĆ M., OSTOJIĆ-ANDRIĆ D., NOVAKOVIĆ Ž. (2010b): Heritability of type traits in first calving Black and White cows. Archiv fur Tierzucht, 53, 5, 545-554.

SMITH L.A., CASSELL B.G., PEARSON R.E. (1998): The effects of inbreeding on the lifetime performance of dairy cattle. J. Dairy Sci., 81, 2729-2737.

STOJIĆ P., ŽIVANOVIĆ L., BESKOROVAJNI R., NIKOLIĆ R., MARKOVIĆ N. (2002): Značaj linearne ocene tipa u odgajivačkim programima mlečnih goveda. Biotehnologija u stočarstvu, 18, 5-6, 31-35.

SWALVE H.H. (2003): New breeding approaches for functional traits. Arch.Tierz., 46, Special Issue, 63-71.

VAN DORP T.E., DEKKERS J.C.M., MARTIN S.W., NOORDHUIZEN J.P.T.M. (1998): Genetic parameters of health disorders and relationships with 305 day milk yield and conformation traits in canadian Holstein. J. Dairy Sci., 81, 8, 2264-2270. ŽIVANOVIĆ L. (2002): Varijabilnost linearno ocenjenih osobina tipa i mlečnosti prvotelki crno-bele rase. Magistarska teza, Poljoprivredni fakultet, Beograd.

WEIGEL K.A., LAWLOR J.R., VANRADEN P.M., WIGGANS G.R. (1998): Use of linear type and production data to supplement early predicted transmitting abilities for productive life. J. Dairy Sci., 81, 7, 2040-2044. 